\title{
Innovation in Acceleration of Community Empowerment with Information Technology Applications: An Action Research Experience
}

\author{
Darmanto Sahat Satyawan \\ Department of Public Administration, Jenderal Soedirman University \\ xonia_nauli@yahoo.co.id
}

\begin{abstract}
The National Program for Community Empowerment in Rural Areas (PNPM-MPd) have been implemented since 2006. PNPM-MPd is a community development program that aims to encourage the strengthening of local communities, especially poor families to get a better quality of life. PNPM-MPd is believed to have a positive impact on poverty reduction at the national level. Beneficiaries of PNPM-MPd so far have received funding from the government to run their business. Entrepreneurial skills of PNPM-MPd actors become important to take into account because the old paradigm states giving the hook, not the fish or giving independent assistance not instant relief is not an easy process. The action research was undertaken with providing guidance to community group in 2013 and 2014, with the introduction of online stores and websites. After the construction of the website, the actors of PNPM-MPd were trained and assisted to manage their websites and online stores. Results of this study show that community empowerment will occur faster with support of information technology and competent assistants.
\end{abstract}

Keywords-capacity, target groups, online stores, websites and empowerment.

\section{INTRODUCTION}

PNPM-MPD is believed to have a positive impact on poverty reduction at the national level. At the local level, the poverty rate in Banyumas decreased $5 \%$ during period of 2008 to 2009 , which was previously $33.6 \%$, then reduced $27.4 \%$, from approximately 1.5 million inhabitants. PNPMMPD contributes positively to poverty reduction in Banyumas. Empowerment process in PNPM-MPD such as productive economic activities, savings and loans, market and infrastructure improvements have been supporting the smooth economy of the rural people. Since 2008, funds were already disbursed through PNPM achieved Rp. 147.5 billion and for 2010 it was revolved amount to $\mathrm{Rp} 45.0$ billion of funding from the Direct Aid for Society from the State Budget (APBN BLM) accompanied by a budget allocation of the regency budget amounting to $\mathrm{Rp} 6.0$ billion or $20 \%$. The fund is revolved for 19 districts distributed to 234 villages, (http://sigapbencana-bansos.info/pantauan-media/6801-pnpmturunkan-kemiskinan.html, accessed on March 13, 2011).

Implementation performance of PNPM-MPD in Banyumas is a pretty good. This is evidenced by: (1) The number of workers absorbed during the program amounted to 19,223 people; (2) Number of beneficiaries of men and women quite balanced: 108,600 men versus 103,772, excluding the beneficiaries of the women in the women's credit program (SPP); (3) The number of beneficiaries of poor households (RTM) is 110,713 inhabitants which is equal to $52 \%$ of the beneficiaries; (4) The number of activities that have been implemented are 475 activities. PNPM-MPD revolved amounting to $\mathrm{Rp}$. $36,020,325,700$ has been successfully stimulated the self-reliant funds amounting to $\mathrm{Rp}$. 2,093,819,188.

Referring to results of research conducted by Indiahono, Satyawan, and Nuraini (2011 and 2012), which showed that the implementation performance is influenced by: the capacity of the implementing agency, the capacity of the target group, the quality of communication and dissemination, as well as monitoring. The study results showed that the capacity of the target group and the implementing agency were two variables that most affect the performance of the implementation of PNPM-MPD. It has become an inspiration to try to improve the performance of the implementation of PNPM-MPD in Banyumas by intervening the capacity of PNPM-MPD actors (both the implementing agency and the target group). In 2013 and 2014 there has been efforts to improve the performance of target groups in the Sub districts of Sumbang and Ajibarang. One of the efforts was to provide guidance and create a website to improve marketing performance and capacity of the target group in terms of publishing activities and product groups.

Therefore, this study focuses on two issues: (1) the impact of assistance and the creation of websites on the capacity building and community empowerment and (2) the response of the target group on information technology.

\section{II.METHOD}

The study was conducted with a qualitative descriptive methods based action. Various parties were selected to be informants, and studied the actions taken by community to strengthen empowerment process. Informants consisted of actors of PNPM-MPD, the manager of the website and the chairman of the target group in two sub districts: Sumbang and Ajibarang. 


\section{III.RESULTS AND DISCUSSION}

Implementing Agency Units (UPK) of PNPM-MPD at sub district of Sumbang and Ajibarang are two very cooperative managers at the local level in this research of empowerment. UPK of PNPM-MPD currently manages activities of PNPM-MPD in 14 villages, with 22 miscellaneous businesses and 137 savings group. PNPMMPD actors actually have a strong passion for both developed and developing, but they do not have the knowledge of how they develop themselves.

The approach used is to increase the capacity of actors PNPM-MPD in Sub Districts of Sumbang and Ajibarang. The actors should be able to recognize their potential and design a marketing agenda in accordance with local advantages. Stages of action that have been made are: (1) Introduction to Marketing Through virtual media, (2) Facilitating the creation of websites and online stores that fit the needs of the general audience; (3) Conducting Assistance / Consultancy in the management of websites and online stores.

At the initial stage, the target group was asked for discussing on modern marketing through the online store. The target group of this stage was very interested and enthusiastic, even they gave ideas of the website created not only to shop but also the official website for promoting the activities. At this stage actors also proposed ideas of a menu to be displayed in the website, view pictures, logos and icons.

At the next stage, the target groups were given training in management of websites and online stores. The target groups who have a relatively young age on average and familiar with internet activities seemed no difficulties in receiving training session. Having held a short training, the website was launched and then disseminated to the public in the $\mathrm{Su}$ District of Sumbang and Ajibarang.

This activity indicates that the UPK of PNPM-MPD in Sumbang and Ajibarang has a different position. The analysis of the position is undertaken based on products that will be sold to consumers where and how to distinguish them from competitor products (Grewal and Levy, 2010: 263). Analysis of the different positions is a part of creating the value of a product. The necessary way is through innovation, which is a process that transform a product into new one and services so that businesses can develop (Grewal and Levy, 2010: 341).

The community must be trusted that without their full involvement, improvement of the quality of their lives will not bring meaningful results (Aziz, Suhartini and Halim, 2005: 7). Actors of PNPM-MPD have been given the working capital adequately. The obstacles they face are how to manage and develop the business so that enterprises supported by the PNPM-MPD can be run in a sustainable manner. Actors of PNPM-MPD require efforts to increase their capacity. Soetomo said that the more urgent in empowerment process is developing the human to be able to be an actor of community formation (Soetomo, 2009: 252).

Capacity development of actors PNPM-MPD in the village become warm to discuss because rural development is recognized very strategically in driving the indigenous economy and the people's welfare redistribution. The debate about growth, poverty and social justice has become an interesting debate and discussion (Kanbur, 2005; Chatterjee 2005 and Smeeding, 2005).
The need of Capacity building for the actors of PNPMMPD should be in line with the needs of the subject of development in terms of capacity building of human resources. Conceptually, the development should not only focus on natural resources that will always be declining. Instead, it should be oriented on increasing social capital and human capital (Serageldin: 1996, as cited by Nugroho, 2004: 224).

One of the effort to increase the capacity of the target groups is through education and training. The actors of the development program are given adequate provisions in order to implement the program properly. The implementing agency must also have the ability to assist the actors of program, so they are able to monitor the program and implement on the right track to achieve the ultimate goal of the program.

\section{CONCLUSION}

This study draw conclusion that the target group of PNPM-MPD has a good attitude towards change. Enthusiasm to learn and develop themselves is an important asset in the success of a program of empowerment. Information technology as one of the resources, should be introduced in the empowerment of the target group. Information technology will help the target group to market products resulted by the community group, so it can accelerate the performance of poverty reduction programs, especially in rural areas. Practical implication of this study suggests that the Banyumas Regency should take into efforts to improve the capacity of the target group account in order to improve the performance of PNPM-MPD, and to introduce information technology in community empowerment process.

\section{REFERENCES}

[1] Aziz, M, Suhartini, Rr dan Halim, A (2005) Dakwah Pemberdayaan Masyarakat: Paradigma Aksi Metodologi. Pustaka Pesantren dan Dakwah Press Fakultas Dakwah IAIN Sunan Ampel Surabaya. Yogyakarta.

[2] Chatterjee, S (2005) Poverty Reduction Strategies-Lessons from the Asian and Pacific Region on Inclusive Development. Asian Development Review. 22. 1. ABI/INFORM Global pg. 12.

[3] Grewal, D and Levy, M (2010) Marketing. Second Edition. New York: McGraw-Hill International Edition.

[4] Kanbur, R (2005) Growth, Inequality And Poverty: Some Hard Questions. Journal of International Affair. Spring. 58, 2; ABI/INFORM Global pg. 223.

[5] Smeeding, TM (2005) Public Policy, Economic Inequality, and Poverty: The United States in Comparative Perspective. Social Science Quarterly. 86. Academic Research Library pg. 955.

[6] Soetomo (2009) Strategi-Strategi pembangunan Masyarakat, Pustaka Pelajar, Yogyakarta.

[7] Supriyanto (2009) Business Plan Sebagai Langkah Awal Memulai Usaha. Jurnal Ekonomi \& Pendidikan, Volume 6 Nomor 1, April 2009 